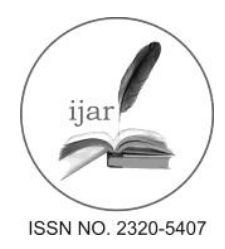

Journal homepage: http://www.journalijar.com

Journal DOI: 10.21474/IJAR01

INTERNATIONAL JOURNAL

OF ADVANCED RESEARCH

RESEARCH ARTICLE

\title{
EFFECTIVENESS OF SOYA BEAN SUPPLEMENTATION ON MEMORY AMONG SCHOOL CHILDREN AT SELECTED SCHOOLS, NELLORE.
}

\author{
"B Rama harika ${ }^{1}$, Radhika $\mathbf{M}^{2}$, Indira.S . \\ 1. Assist.prof, Dept of Child Health Nursing, Narayana College of nursing, Nellore, Andhra Pradesh, India. \\ 2. Professor, Dept of Child Health Nursing, Narayana College of nursing, Nellore, Andhra Pradesh. \\ 3. Principal, Medical surgical Nursing, Narayana College of nursing, Nellore, Andhra Pradesh.
}

\section{Manuscript Info}

\section{Manuscript History:}

Received: 16 March 2016

Final Accepted: 19 April 2016

Published Online: May 2016

Key words:

soya beans, memory, school children.

*Corresponding Author

B Rama harika.

\section{Abstract}

Introduction:- During school years children become increasingly capable of and responsible for self-care activities. The ability of mind to store the past experiences of learning and utilizing them is known as memory. The development of memory in children becomes evident within first 2-3 years of a child's life as show considerable advances in declarative memory. This enhancement continues into adolescence with major developments in short term memory, long term memory. Soya bean is hailed as the most protective bean. Soya beans contain $40 \%$ protein as compared to other legumes which contain $20 \%$ protein. It has the highest protein content amongst plant products.

Objective: - The objective of this study was to evaluate the effectiveness of soya bean supplementation on memory of schoolchildren available in selected schools of Nellore, Andhra Pradesh.

Methodology:- A True -Experimental study was conducted in Z.P.H.School, located in T.P.Gudur, at Nellore District. Sample sizes of 60 school age children were selected by using stratified random sampling technique. Modified PGI Memory scale was used to assess the memory of a child.

Results:- The results reveal that with regard to memory status of the school children, in experimental group, during pre test, 19 (63.3\%) children had very good memory and $11(36.7 \%)$ had good memory whereas in post test, $29(96.7 \%)$ children had very good memory and $1(3.3 \%)$ had good memory. In control group during pre test, $18(60 \%)$ children had very good memory and $12(40 \%)$ had good memory whereas in post test, 19(63.3\%) children had very good memory and $11(36.7 \%)$ had good memory.

Conclusion:- The study concluded that there is a significant association between soya bean supplementation and, memory. There is a significant in improvement of Memory in experimental group as compared to the control group. This shows that administration of soya beans in improvement of Memory is very effective and cost effective in the enhancement of academic performance. 


\section{Introduction:-}

Nutrition is the combination of dynamic process by which the consumed food is utilized for nourishment for structural and functional efficiency of every cell of the body, it helps to sustain the body and mind and keep it healthy. During school years children become increasingly capable of and responsible for self-care activities. The energy and nutrient needs may vary from birth to pre-school and school going ages, there are specific recommended number of servings for each of the food group for different age groups. The proteins required for the school children are 4-6 grams/kg/day as per Recommended Dietary Allowances .

The ability of mind to store the past experiences of learning and utilizing them is known as memory. The development of memory in children becomes evident within first 2-3 years of a child's life as show considerable advances in declarative memory. This enhancement continues into adolescence with major developments in short term memory, long term memory. ${ }^{2}$

Soya bean is hailed as the most protective bean. Soya beans contain $40 \%$ protein as compared to other legumes which contain $20 \%$ protein. It has the highest protein content amongst plant products. Soya bean is the only vegetable food that contains all essential amino acids. Soya beans contain $19 \%$ unsaturated fat, 8 grams of dietary fiber, 200 to $300 \mathrm{mg}$ of calcium, 4.3 grams of carbohydrates and abundant isoflavones. ${ }^{3}$

Lecithin is the component of lipids, and Isoflavones, phosphatidyl serine in the soya beans are responsible for improvement of memory by acting as a neurotransmitters. ${ }^{4}$

\section{Objectives:}

* To assess the memory among school children.

* To evaluate the effectiveness of soya bean supplementation on memory among school children in experimental group.

* To associate effectiveness of soya bean supplementation on memory of children with their selected socio demographical variables.

\section{Materials and methods:-}

The study was conducted by using True experimental pre test and post test design. Subjects were selected by using the probability stratified sampling technique. 60 samples were selected based on the sampling criteria and screened for memory status by using modified PGI memory scale. Among 60 school children, 30 were allotted to experimental group and 30 to control group. 15 grams of cooked Soya beans supplementation was given twice a day for 28 days and post test was conducted on $30^{\text {th }}$ day. The data was analyzed by using the descriptive and inferential statistics and tabulated according the objectives and hypothesis of the study.

Ethical Clearance: - There was no drug administration or invasive procedure involved in the study. A written permission was obtained from the institutional authority and ethical committee. Written informed consent was obtained from mothers of children and who participated in the study and Confidentiality and anonymity of the subjects was maintained throughout the study. ${ }^{5}$ (HARIKA, 2015) 
Results \& discussion:-

Table 1: Distribution of Demographic Variables of child $\quad(\mathbf{N}=\mathbf{6 0})$

\begin{tabular}{|c|c|c|c|c|c|}
\hline \multirow[t]{2}{*}{ S.No } & \multirow[t]{2}{*}{ Demographic Variables } & \multicolumn{2}{|c|}{$\begin{array}{c}\text { Experimental group } \\
(\mathbf{n}=\mathbf{3 0})\end{array}$} & \multicolumn{2}{|c|}{ Control group $(\mathrm{n}=30)$} \\
\hline & & $\mathrm{f}$ & $\%$ & $\mathrm{f}$ & $\%$ \\
\hline 1. & $\begin{array}{c}\text { Age } \\
\text { a) } 11-12 \\
\text { b) } 12-13 \\
\text { c) } 13-14 \\
\end{array}$ & $\begin{array}{c}6 \\
7 \\
17\end{array}$ & $\begin{array}{c}20 \\
23.3 \\
56.7\end{array}$ & $\begin{array}{c}5 \\
3 \\
22\end{array}$ & $\begin{array}{c}16.7 \\
10 \\
73.3\end{array}$ \\
\hline 2. & $\begin{array}{l}\text { a)Boys } \\
\text { b)Girls }\end{array}$ & $\begin{array}{l}15 \\
15\end{array}$ & $\begin{array}{l}50 \\
50 \\
\end{array}$ & $\begin{array}{l}15 \\
15\end{array}$ & $\begin{array}{l}50 \\
50 \\
\end{array}$ \\
\hline 3. & $\begin{array}{l}\text { Religion } \\
\text { a)Hindu } \\
\text { b)Muslim } \\
\text { c)Christian }\end{array}$ & $\begin{array}{c}23 \\
1 \\
6 \\
\end{array}$ & $\begin{array}{l}76.7 \\
3.3 \\
20 \\
\end{array}$ & $\begin{array}{c}19 \\
1 \\
10\end{array}$ & $\begin{array}{c}63.4 \\
3.3 \\
33.3 \\
\end{array}$ \\
\hline 4. & $\begin{array}{l}\text { Education } \\
\text { a) } 6^{\text {th }} \text { standard } \\
\text { b) } 7^{\text {th }} \text { standard } \\
\text { c) } 8^{\text {th }} \text { standard } \\
\text { d) } 9^{\text {th }} \text { standard }\end{array}$ & $\begin{array}{l}7 \\
8 \\
8 \\
7 \\
\end{array}$ & $\begin{array}{l}23.3 \\
26.7 \\
26.7 \\
23.3 \\
\end{array}$ & $\begin{array}{l}8 \\
7 \\
7 \\
8 \\
\end{array}$ & $\begin{array}{l}26.7 \\
23.3 \\
23.3 \\
26.7 \\
\end{array}$ \\
\hline 5. & $\begin{array}{l}\text { Dietary pattern } \\
\text { a)Vegetarian } \\
\text { b)Non- vegetarian }\end{array}$ & $\begin{array}{c}- \\
30 \\
\end{array}$ & $\begin{array}{c}- \\
100\end{array}$ & $\begin{array}{c}1 \\
29\end{array}$ & $\begin{array}{c}3.3 \\
96.7\end{array}$ \\
\hline 6. & $\begin{array}{l}\text { Medium of instruction } \\
\text { a)English }\end{array}$ & 30 & 100 & 30 & 100 \\
\hline 7. & $\begin{array}{l}\text { Age of mother } \\
\text { a) }<30 \\
\text { b) } 30-35 \\
\text { c) } 36-40 \\
\text { d) } 41-45 \\
\text { e)Above } 45\end{array}$ & $\begin{array}{c}7 \\
8 \\
11 \\
2 \\
2\end{array}$ & $\begin{array}{c}23.3 \\
26.7 \\
36.6 \\
6.7 \\
6.7\end{array}$ & $\begin{array}{c}6 \\
8 \\
14 \\
2 \\
-\end{array}$ & $\begin{array}{c}20 \\
26.7 \\
46.6 \\
6.7 \\
-\end{array}$ \\
\hline 8. & $\begin{array}{c}\text { Education of mother } \\
\text { a)Illiterate } \\
\text { b)Primary education } \\
\text { c)Secondary education } \\
\text { d)Higher secondary education }\end{array}$ & $\begin{array}{c}9 \\
10 \\
11 \\
-\end{array}$ & $\begin{array}{c}30 \\
33.3 \\
36.7 \\
- \\
\end{array}$ & $\begin{array}{c}8 \\
6 \\
14 \\
2 \\
\end{array}$ & $\begin{array}{c}26.7 \\
20 \\
46.6 \\
6.7 \\
\end{array}$ \\
\hline 9. & $\begin{array}{l}\text { Occupation of mother } \\
\text { a)House wife } \\
\text { b)Coolie } \\
\text { c)Private employee } \\
\text { d)Government employee }\end{array}$ & $\begin{array}{c}15 \\
14 \\
1 \\
-\end{array}$ & $\begin{array}{c}50 \\
46.7 \\
3.3 \\
-\end{array}$ & $\begin{array}{c}18 \\
9 \\
1 \\
2\end{array}$ & $\begin{array}{l}60 \\
30 \\
3.3 \\
6.7\end{array}$ \\
\hline 10. & $\begin{array}{l}\text { Family income } \\
\text { a) }<5000 \mathrm{Rs} /- \\
\text { b)Rs } 5001-7000 /- \\
\text { c) Rs 7001-9000/- } \\
\text { d)Rs9001-11000/- }\end{array}$ & $\begin{array}{c}15 \\
6 \\
7 \\
2\end{array}$ & $\begin{array}{c}50 \\
20 \\
23.3 \\
6.7\end{array}$ & $\begin{array}{c}11 \\
8 \\
8 \\
3\end{array}$ & $\begin{array}{c}36.6 \\
26.7 \\
26.7 \\
10\end{array}$ \\
\hline 11. & $\begin{array}{l}\text { Place of residence } \\
\text { a) Sub urban }\end{array}$ & 30 & 100 & 30 & 100 \\
\hline 12 & $\begin{array}{c}\text { Medical history } \\
\text { a)Normal }\end{array}$ & 30 & 100 & 30 & 100 \\
\hline
\end{tabular}


Table.1 reveals in relation to socio demographic variables, among the 60 school children, with regard to the age group, $17(56.6 \%)$ school children were between 13-14years, regard to religion 23 (76.7\%) school children were Hindus, regarding to medium of instruction all $100 \%$ children studying in English medium, regard to eating pattern $29(96.7 \%)$ children were non vegetarians, regard to family income $15(50 \%)$ children family income was less than Rs5000/- per month, With regard to education of children's mothers $11(36.7 \%)$ were studied up to secondary education.

Table.No-2:- Frequency and percentage distribution of Memory status of school children in Experimental and Control group.

\begin{tabular}{|c|c|c|c|c|}
\hline \multirow[t]{2}{*}{ MEMORY STATUS } & \multicolumn{2}{|c|}{$\begin{array}{c}\text { PRE TEST } \\
(n=30)\end{array}$} & \multicolumn{2}{|c|}{$\begin{array}{c}\text { POST TEST } \\
(n=30)\end{array}$} \\
\hline & $\mathbf{f}$ & $\%$ & $\mathbf{f}$ & $\%$ \\
\hline $\begin{array}{l}\text { Experimental group } \\
\text { a)Very Good memory } \\
\text { b)Good memory }\end{array}$ & $\begin{array}{l}19 \\
11\end{array}$ & $\begin{array}{l}63.3 \\
36.7\end{array}$ & $\begin{array}{c}29 \\
1\end{array}$ & $\begin{array}{c}96.7 \\
3.3\end{array}$ \\
\hline Total & 30 & 100 & 30 & 100 \\
\hline $\begin{array}{l}\text { Control group } \\
\text { a)Very Good memory } \\
\text { b)Good memory }\end{array}$ & $\begin{array}{l}18 \\
12 \\
\end{array}$ & $\begin{array}{l}60 \\
40 \\
\end{array}$ & $\begin{array}{l}19 \\
11 \\
\end{array}$ & $\begin{array}{l}63.3 \\
36.7 \\
\end{array}$ \\
\hline Total & 30 & 100 & 30 & 100 \\
\hline
\end{tabular}

Table.No-2-shows that with regard to memory status of the school children, in experimental group, during pre test, $19(63.3 \%)$ children had very good memory and 11 (36.7\%) had good memory whereas in post test, 29 (96.7\%) children had very good memory and $1(3.3 \%)$ had good memory. In control group during pre test, 18(60\%) children had very good memory and $12(40 \%)$ had good memory whereas in post test, 19(63.3\%) children had very good memory and $11(36.7 \%)$ had good memory.

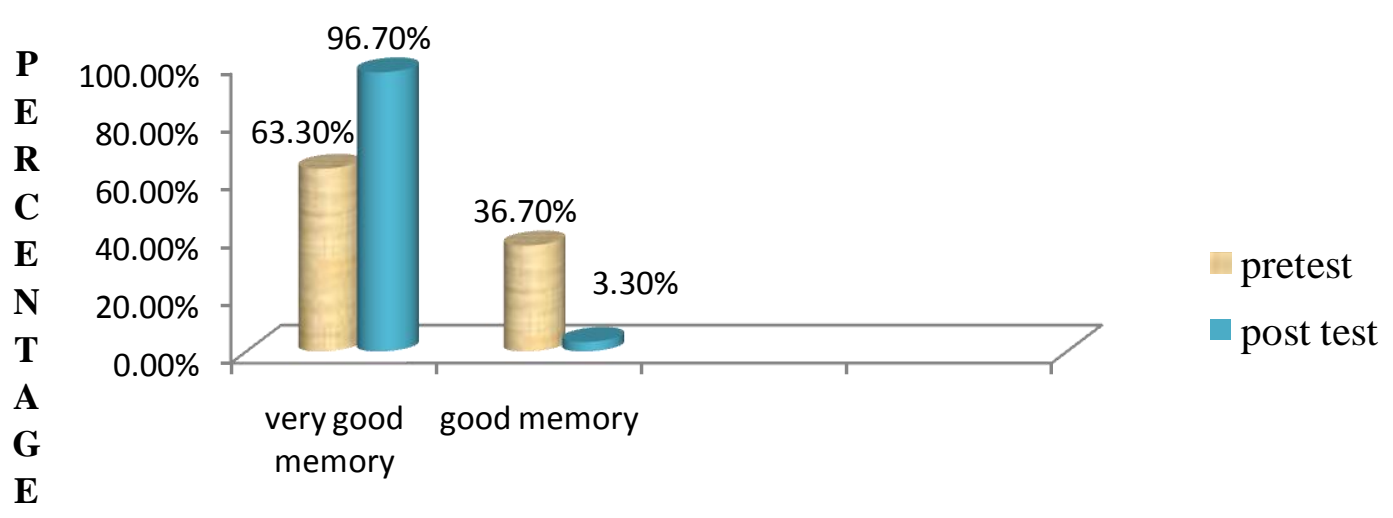

MEMORY STATUS IN EXPERIMENTAL GROUP

Fig no.1:- percentage distribution of Memory status of school children in Experimental group 


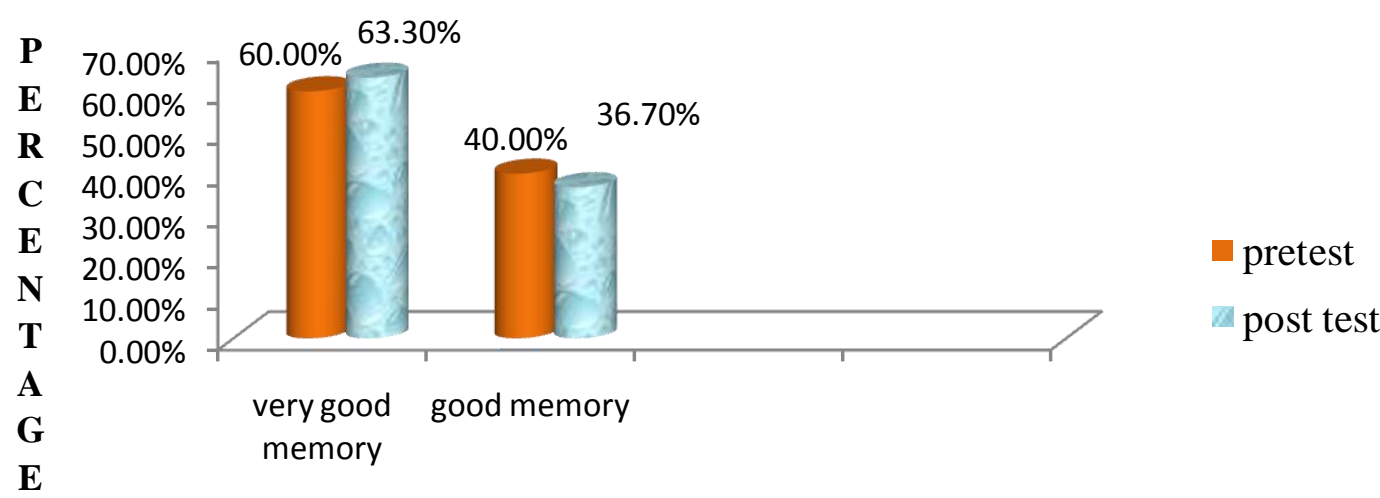

MEMORY STATUS IN CONTROL GROUP

Fig no.2:- percentage distribution of Memory status of school children in Experimental group.

Table.No-3:- Comparison of Mean, Standard deviation of memory status among school children in both control and experimental group.

\begin{tabular}{|c|c|c|c|c|c|c|}
\hline \multirow{2}{*}{ S.No } & \multirow[t]{2}{*}{ Memory status } & \multicolumn{2}{|c|}{ Experimental group } & \multicolumn{2}{|c|}{ Control group } & \multirow[t]{2}{*}{ Paired "t" test } \\
\hline & & Mean & $\begin{array}{l}\text { Standard } \\
\text { Deviation }\end{array}$ & Mean & $\begin{array}{l}\text { Standard } \\
\text { Deviation }\end{array}$ & \\
\hline 1. & Pre test & 81.06 & 4.201 & 86.86 & 4.793 & $\begin{array}{c}\mathrm{Cal}=5.744 \\
\mathrm{Tab}=3.659 \\
\mathrm{P}<0.001 \\
\mathbf{S}^{* * *}\end{array}$ \\
\hline 2 & Post test & 81.43 & 4.588 & 81.80 & 4.32 & $\begin{array}{c}\mathrm{Cal}=0.432 \\
\mathrm{Tab}=3.659 \\
\mathrm{P}<0.001 \\
\mathbf{N S}\end{array}$ \\
\hline
\end{tabular}

S*** - Very highly Significant at $\mathrm{P}=<0.001$, df $(\mathrm{n}-1)=29$

NS -Non Significant at $\mathrm{P}=<0.001$, df $(\mathrm{n}-1)=29$

Table.No-3 shows the effectiveness of Soya bean supplementation among school children in Experimental Group. The pre test mean is 81.006 with standard deviation of 4.201 . The post test means is 86.866 with standard deviation of 4.793.The calculated value of paired "t-test" is 5.744 and the table value is 3.659. The calculated value is Greater than table value hence, the null hypothesis is rejected and research hypothesis is accepted. After soya bean supplementation the mean values of memory score are increased from 81.06 to 86.86 . Hence research hypothesis accepted.

Effectiveness of Soya bean supplementation among school children in Control Group. The pre test mean is 81.433 with standard deviation of 4.558 . The post tests mean is 81.80 with standard deviation of 4.32 . The calculated value of "paired t-test" is 0.432 and the table value is 3.659 . The calculated value is lesser than table value hence, the null hypothesis is accepted and research hypothesis is rejected.

\section{Association between the post test Memory score and the socio demographic variables in Experimental group:-}

There is a significant association between post test memory scores and some socio demographic variables which includes age of child, education of child.

Association between the post test Memory score and the socio demographic variables in Control group:There is a significant association between post test memory scores and some socio demographic variables which includes age of child, education of child. 


\section{Conclusion:-}

The study reveals that there is a significant association between soya bean supplementation and, memory. There is a significant in improvement of Memory in experimental group as compared to the control group. This shows that administration of soya beans in improvement of Memory is very effective and cost effective in the enhancement of academic performance.

\section{References:-}

1. WPT James, A Ralph. Food and Nutrition. $2^{\text {nd }}$ ed. London: Elsevier; 2004.p.212-14.

2. Swaminathan. Food and Nutrition. Banglore: Bappco; 2009.p.346-48.

3. Fernald. Introduction to Psychology. $5^{\text {th }}$ ed. New Delhi: A.I.T.B.S; 2003.P.231-40.

4. Afsaneh hassabeigi, Jafar Askari, Shima shikoda. Administration of soya bean lecithin. J Nutr [Serial online] 2011 Mar-May [cited 2011 Oct 21]; 131(11). Available from: URL:http://edu.acad.ac.uk

5. Rama Harika, Radhika M, Indira S.A comparative study to evaluate the effectiveness of lateral position versus supine position on respiratory parameters among infants with respiratory problems. International Journal of applied research vol.1, Issue 12, pp 935-940, 2015

6. Masashi sakai, Rika Ebina. Efeects of soy on cognition. J.Nutr. 2012 april 16; 13(7): 43-45.

7. D.Hollar et.al. Soy effectiveness on memory. BJN. 2009 June 16;11(3):27-28. 